\title{
Bacterial abundance, biomass, and production in relation to phytoplankton biomass in the Levantine Basin of the southeastern Mediterranean Sea
}

\author{
Richard D. Robarts $^{1, *}$, Tamar Zohary ${ }^{2}$, Marley J. Waiser ${ }^{1}$, Y. Z. Yacobi ${ }^{2}$ \\ 'National Hydrology Research Institute, Environment Canada, 11 Innovation Blvd, Saskatoon, Saskatchewan, \\ Canada $57 \mathrm{~N} 3 \mathrm{H5}$
}

${ }^{2}$ Yigal Allon Kinneret Limnological Laboratory, Israel Oceanographic and Limnological Research, PO Box 345, Tiberias, Israel 14102

\begin{abstract}
Little is known about the relative significance of heterotrophic bacteria in open-ocean oligotrophic environments. The pelagic waters of the Levantine Basin of the eastern Mediterranean Sea are among the most oligotrophic on record. We surveyed the spatial distribution of bacterial abundance, biomass and production along 2 transects of the pelagic waters of the southern Levantine Basin to assess which changes in these parameters may occur in association with varying physical structure and chlorophyll concentrations, to calculate the relative biomass contributions of bacteria and phytoplankton, and to estimate the magnitude of carbon flux from phytoplankton to bacteria. Chlorophyll had an average concentration of $134 \pm 85.4 \mathrm{ng} \mathrm{l}^{-1}$ and was relatively uniform throughout the upper

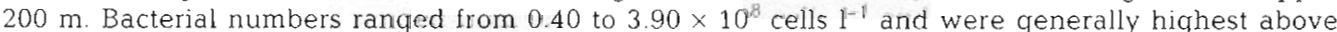
$110 \mathrm{~m}$. Cocci cells comprised $87 \%$ of the population with an average volume of $0.049 \mu^{3}$ Bacterial numbers and biomass were notably high in the lerapetra Eddy and Mersa Matruh Gyre. Although bacterial numbers and chlorophyll concentrations were not generally correlated, the mean bacterial numbet was accurately predicted from a regression equation using chlorophyll. Over the upper $200 \mathrm{~m}$, bacterial biomass $\left(\bar{x}=603 \mathrm{mgC} \mathrm{m}^{-2}\right)$ was on average about $50 \%$ of phytoplankton biomass $(\bar{x}=1235 \mathrm{mgC}$ $\mathrm{m}^{-2}$ ), which is contrary to other published studies reporting bacterial biomass equalled or exceeded algal biomass in oligotrophic marine waters. Bacterial production ranged from 0 to 3.91 pmol TdR 1-1 $\mathrm{h}^{-1}$ Average bacterial carbon production varied from $1.76 \mathrm{ng} \mathrm{l}^{-1} \mathrm{~h}^{-1}$ at $150 \mathrm{~m}$ to $9.09 \mathrm{ng} \mathrm{l}^{-1} \mathrm{~h}^{-1}$ at $100 \mathrm{~m}$. Specific growth rates reached a maximum value of $0.54 \mathrm{~d}^{-1}$ at $100 \mathrm{~m}$ while mean doubling time was $70.8 \pm 180.9 \mathrm{~d}$. Mean daily bacterial production for the upper $200 \mathrm{~m}$ was $24.3 \mathrm{mgC} \mathrm{m}^{-2} \mathrm{~d}^{-1}$, indicating bacteria could consume on average $154 \%\left(69.3 \mathrm{mgC} \mathrm{m}^{-2} \mathrm{~d}^{-1}\right)$ of phytoplankton primary production. Our calculations indicate that the bacterial population may be acquiring organic carbon not derived from phytoplankton. In order to confirm this imbalance of carbon flux from phytoplankton to heterotrophic bacteria in the Levantine Basin, good estumates of water column primary production, which do not exist, must be obtained
\end{abstract}

KEY WORDS: Bactenal production Bacterial biomass Thymidine incorporation Mediterranean Sea Oligotrophic ocean

\section{INTRODUCTION}

Bacteria contribute significantly to microbial food webs and biogeochemical cycles in marine ecosystems (Ducklow \& Carlson 1992). In oligotrophic oceans bacteria often consume up to half of the primary production via dissolved organic matter and in turn are con-

·E-mail: robartsr@nhrisv.nhrc.sk.doe.ca sumed by protistan grazers (Azam et al. 1983). Most studies have been carried out in coastal systems while data from oligotrophic offshore waters are scarce. Consequently little is known about the relative significance of heterotrophic bacteria in open-ocean oligotrophic environments (Fuhrman et al. 1989. Ducklow \& Carlson 1992). Recent studies have found that in oligotrophic oceans bacterial biomass often exceeds that of phytoplankton (Cho \& Azam 1990). As noted by 
Fuhrman et al. (1989), knowledge of microbial processes in these waters is necessary for studying interactions on a global scale as they make up a significant portion of the world ocean.

The pelagic waters of the Levantine Basin of the eastern Mediterranean Sea are among the most oligotrophic on record, with exceptionally low primary productivity (Berman et al. 1984), chlorophyll and nutrient concentrations in summer (Salihoglu et al. 1990, Krom et al. 1991, Yacobi et al. 1995). Significantly higher nutrient concentrations ( $5 \mu \mathrm{M}$ nitrate and $0.2 \mu \mathrm{M}$ phosphate) are found beneath the nutricline (ca $200 \mathrm{~m}$ ) and are advected into the upper mixed layer during deep mixing events in winter (Hecht et al. 1988). Increased nutrient concentrations may be found in summer as a result of physical forces causing water mass movements such as upwelling. Further, a warm core eddy south of Cyprus and the cold core eddy near Riludes are locaiized sites of nutrient enrichment which may support higher biological activity than in the basin generally (Yacobi et al. 1995).

To our knowledge only one study has examined hetcrotrophic bacterial abundance and production in the eastern Mediterranean Sea and this was confined to the core and boundary of the Cyprus Eddy (Zohary \& Robarts 1992). We found that bacterial numbers in the euphotic zone were close to the lower threshold value for bacterial abundance in oceans, with means of $2.7 \times$ $10^{8}$ cells $l^{-1}$ at the boundary and $4.9 \times 10^{8}$ cells $l^{-1}$ at the core. Bacterial production, as the rate of labelled thymidine (TdR) incorporation into bacterial DNA, ranged from 0.01 to $0.70 \mathrm{pmol} \mathrm{TdR} \mathrm{l}^{-1} \mathrm{~h}^{-1}$, values which are at the lower end of ranges reported from other aquatic systems (Ducklow \& Carlson 1992, Zohary \& Robarts 1992). The doubling times for bacteria were about $50 \mathrm{~d}$.

In the work reported here, we surveyed the spatial distribution of bacterial abundance, biomass and production along 2 transects of the pelagic waters of the southern Levantine Basin (Fig, 1). Our objectives were: to determine if the values we recorded in the Cyprus Eddy were characteristic of the basin generally; to assess which, if any, changes in these parameters may occur in association with varying physical structure and chlorophyll concentrations; to calculate the relative biomass contributions of bacteria and phytoplankton; and to estimate the magnitude of carbon flux from phytoplankton to bacteria. Our study was undertaken concomitantly with the synoptic survey of chlorophyll concentrations in the basin by Yacobi et al. (1995).

\section{METHODS}

Data were collected from the RV 'Shikmona' during the LBDS03 (Levantine Basin Dynanic Siudy ${ }_{H 3}$ ) cruise to the southern Levantine Basin between Israel and Crete. This cruise was also part of the POEM-BC 091 multinational programme. During 2 periods (14 to 24 October and 6 to 11 November 1991) a quasicontinuous profile of temperature and salinity versus depth was measured at each station by a Neil-Brown conductivity-temperature-depth profiler (CTD). A rosette containing twelve 1.7 l Niskin bottles (General Oceanics) was mounted on the CTD. The bottles were closed on the upcast.

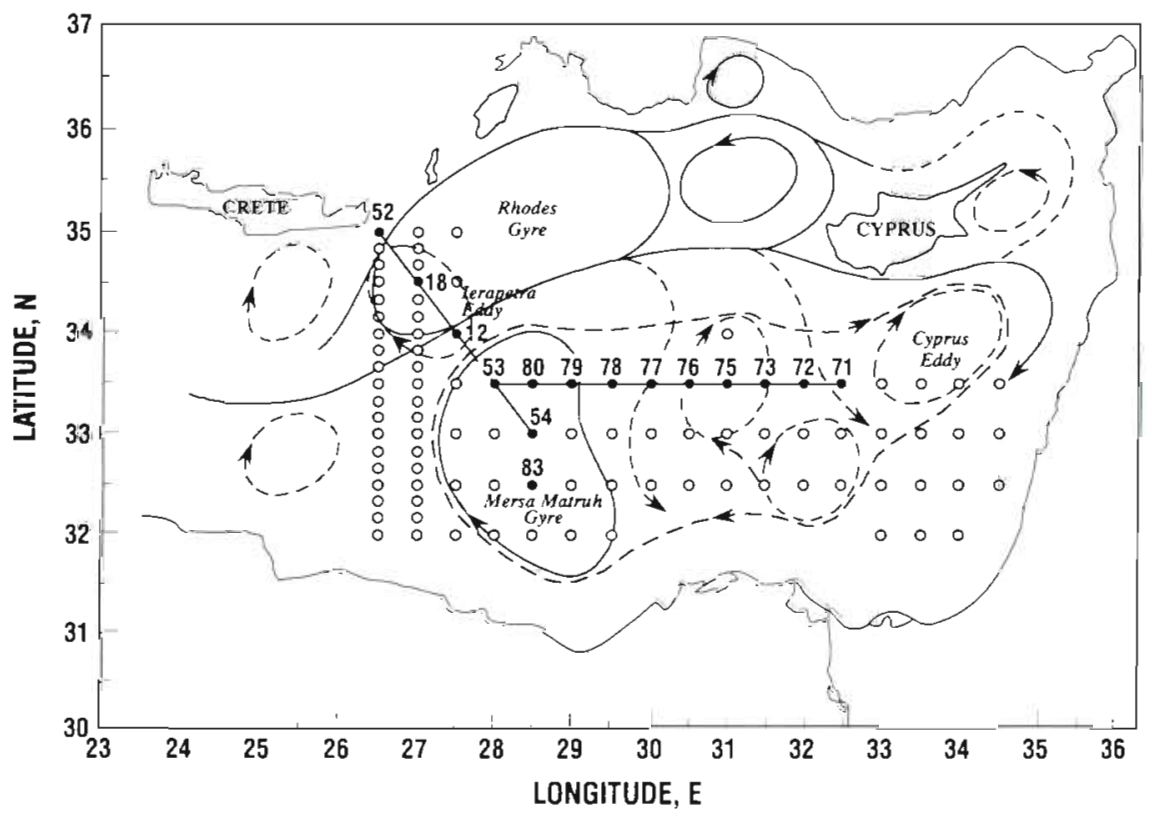

Fig. 1 Map of the eastern Mediterranean research area, constructed from data in Robinson et al. (1991), Robinson \& Golnaraghi (1993) and Yacobi et al. (1995), showing the dominant mesoscale physical features and the NW-SE and W-E sampling transects (bold lines). (0) Sampling stations of Yacobi et al. (1995). station numbers are for the present study and are the same numbers as used by Yacobi et al. (1995). Solid lines indicate permanent gyres and jets and broken lines show recurrent or transient features 
Table 1 . Depth to which $1 \%$ and $0.1 \%$ surface photosynthetically active radiation (PAR) penetrated in the Eastern Mediterranean as calculated using the Secchi disc depth (Yacobi et al. 1995) and the equation of Megard \& Berman (1989). Station locations are given in Fig. 1

\begin{tabular}{|cccc|}
\hline Stn & $\begin{array}{c}\text { Secchi disc depth } \\
(\mathrm{m})\end{array}$ & $\begin{array}{c}\text { 1\% PAR } \\
(\mathrm{m})\end{array}$ & $\begin{array}{c}0.1 \% \text { PAR } \\
(\mathrm{m})\end{array}$ \\
\hline 52 & 18.0 & 54.7 & 82.1 \\
53 & 27.0 & 82.1 & 123.1 \\
54 & 22.0 & 66.9 & 100.3 \\
72 & 28.5 & 86.6 & 130.0 \\
76 & 30.0 & 91.2 & 136.8 \\
77 & 40.5 & 123.1 & 184.7 \\
83 & 29.0 & 88.2 & 132.2 \\
Mean & 27.9 & 84.7 & 127.0 \\
\hline
\end{tabular}

Water samples were collected at 10 stations on a east-west transect along latitude $33^{\circ} 30^{\prime} \mathrm{N}$ and at 5 stations along a NW-SE transect from $35^{\circ} \mathrm{N}, 26^{\circ} 30^{\prime} \mathrm{E}$ (near Crete) to $33^{\circ} \mathrm{N}, 28^{\circ} 30^{\prime} \mathrm{E}$ (Fig. 1). Samples were obtained from $0,25,50,75,90,100,110,130,170$ and $200 \mathrm{~m}$ at each station and also at 500 and $1000 \mathrm{~m}$ at 3 stations. Secchi disc depth was measured at 7 stations. Using Secchi disc depths and the equation of Megard \& Berman (1989), we calculated that the depth to which $1 \%$ surface photosynthetically active radiation (PAR) penetrated was between 54.7 and $123.1 \mathrm{~m}$ (Table 1). In these very clear waters, however, the depth of $0.1 \%$ PAR penetration ( 82.1 and $184.7 \mathrm{~m}$ ) is probably a better estimate of euphotic zone depth than the depth of $1 \%$ PAR, as usually used for more enriched waters. Water samples for nutrient and chlorophyll concentrations (determined fluorometrically after acetone extraction) were concurrently collected at the same depths (Yacobi et al. 1995). Phytoplankton carbon biomass was calculated from chlorophyll concentrations using a C:chl ratio of 50 (Fuhrman et al. 1989).

Water samples of $50 \mathrm{ml}$ were preserved with the Lugol-formaldehyde solution of Sherr et al. (1989) and kept refrigerated until bacteria were enumerated using epifluorescence microscopy and DAPI stain. Bacterial cell volumes were obtained using an image processing program (Tumber et al. 1993) and bacterial biomass was converted to carbon units using a power function calculated from Simon \& Azam's (1989) data for cell volume and carbon content. Bacterial production was measured using the [methyl- ${ }^{3} \mathrm{H}$ ]thymidine (TdR) incorporation method of Robarts \& Zohary (1993) for oligotrophic waters. TdR was added to water samples at a final concentration of $15 \mathrm{nM}$, and incubation times were $1 \mathrm{~h}$ at ambient temperature. These conditions have been found to be suitable for the TdR assay in these waters (Zohary \& Robarts 1992, Robarts \& Zohary 1993). Bacterial cell production was calculated using the conversion factor of $1 \times 10^{18}$ cells produced $\mathrm{mol}^{-1} \mathrm{TdR}$ incorporated into DNA (Zohary \& Robarts 1992). The time needed for the bacterial population to double was calculated as cell numbers/cell production per day while specific growth rates were calculated as ln2/cell doubling time. Bacterial carbon production was calculated from the rate of cell production using the mean carbon content of cells (see 'Results').

The data from each depth were not pooled but were analysed (Pearson Product Moment Correlation) in 10 separate (depth) categories to remove the possibility of autocorrelation with depth (Legendre \& Troussellier 1988).

\section{STUDY SITE}

In the Levantine Basin during summer there is a well-defined buoyant surface layer that overlays several mesoscale features: the Cyprus Eddy (also called the Shikmona Gyre) south of Cyprus and the Mersa Matruh Gyre along the Egyptian coast (Fig. 1). There is also an intense anticyclonic eddy (lerapetra Eddy) located southeast of Crete that was sectioned by our diagonal NW-SE transect.

The physical structure at Stn 76 was representative of the region during our cruise in late summer: the Levantine surface waters (LSW), a warm $\left(22^{\circ} \mathrm{C}\right.$ ), high salinity (39.4 psu) upper mixed layer extending down to about $35 \mathrm{~m}$; a narrow layer of low salinity (38.8 psu) Atlantic water (AW); a high salinity (39.1 psu) Levantine intermediate water layer (LIW); and at a depth of about $500 \mathrm{~m}$, the cold $\left(13.9^{\circ} \mathrm{C}, 38.8 \mathrm{psu}\right)$ Levantine deep waters (Yacobi et al. 1995). This structure extended across our study area, being disrupted only at Stns 12 and 18 located within the eddy southeast of Crete. At these stations LSW extended to $150 \mathrm{~m}$ and the interface between LSW and AW occurred at about $200 \mathrm{~m}$ (Yacobi et al. 1995). Downwelling to between 200 and $400 \mathrm{~m}$ occurred at these stations and at $\operatorname{Stn} 78$. LIW penetrated to depths greater than $500 \mathrm{~m}$ within the gyres (Yacobi et al. 1995).

Nutrient concentrations varied from $<0.05$ to $6.0 \mu \mathrm{M}$ nitrate, $<0.01$ to $0.28 \mu \mathrm{M}$ orthophosphate and 1.0 to $12.0 \mu \mathrm{M}$ silicic acid (Yacobi et al. 1995). The vertical distribution of nitrate and phosphate was fairly uniform throughout our study area except at the downwelling areas noted above. Nitrate and phosphate concentrations were often close to, or below, the detection limits of the method used in the euphotic zone. Yacobi et al. (1995) found that the nutricline began at about 150 to $200 \mathrm{~m}$ and that maximal nutrient concentrations occurred at about $600 \mathrm{~m}$. In the downwelling areas the nutricline occurred much deeper than $200 \mathrm{~m}$ and with maximal values well below $600 \mathrm{~m}$. 


\section{RESULTS}

Chlorophyll concentrations ranged from $9.2 \mathrm{ng} \mathrm{l}^{-1}$ at $170 \mathrm{~m}$ to $430 \mathrm{ng} \mathrm{l}^{-1}$ at $100 \mathrm{~m}$ (Table 2, Fig 2) with an average of $134 \pm 85.4 \mathrm{ng} \mathrm{l}^{-1}$ (SD) in the upper $200 \mathrm{~m}$ of the water column. As noted by Yacobi et al. (1995), the vertical distribution of chlorophyll was relatively uniform throughout the study area while a distinct DCM (deep chlorophyll maximum) of about $250 \mathrm{ng} \mathrm{l}^{-1}$ at 90 to $110 \mathrm{~m}$ was observed at all stations except 12 and 18 , located in the anti-cyclonic Ierapetra Eddy (Fig. 2). At these stations, there was no distinct DCM and chlorophyll concentrations of about $125 \mathrm{ng} \mathrm{l}^{-1}$ were found throughout the upper $200 \mathrm{~m}$. The integrated concentration of chlorophyll in the upper $200 \mathrm{~m}$ of the water column ranged from 17.4 to $34.2 \mu \mathrm{g} \mathrm{m}^{-2}$ or carbon biomass values of 869 to $1712 \mathrm{mgC} \mathrm{m}^{-2}$ (Fig. 3). The highest algal biomass was associated with the Ierapetra Eddy and Mersa Matruh Gyre southeast of Crete (Stns 52 to 53). Across this NW-SE transect algal biomass generally decreased while along the east-west transect biomass was more constant.

Bacterial numbers were generally highest in the upper water column (upper $110 \mathrm{~m}$ ) and decreased with depth (Figs. 4A \& 5A). In the upper $200 \mathrm{~m}$ bacterial numbers ranged from 0.40 to $3.90 \times 10^{8}$ cells $\mathrm{I}^{-1}$ (Table 2). At 500 and $1000 \mathrm{~m}$ the numbers of bacteria were markedly lower. Above $110 \mathrm{~m}$ bacterial numbers were homogeneously distributed along the east-west transect (Fig. 4A). Along the NW-SE transect bacterial numbers increased from Stn 52 to Stn 12 in the Ierapetra Eddy and then were homogeneous over the remainder of the transect (Fig. 5A). Changes in bacterial numbers were positively correlated with sigma-t at $0 \mathrm{~m}(\mathrm{r}=0.65,0.03)$ and at $25 \mathrm{~m}(r=0.80, \mathrm{p}=0.002)$ and inversely with water temperature at $25 \mathrm{~m}(\mathrm{r}=-0.62$, $\mathrm{p}=0.03$ ). No other significant correlations were found.

Cocci were the dominant cell morphology, representing an average of $87 \%$ of the total population in the upper $200 \mathrm{~m}$. Cocci had a mean diameter of $0.43 \pm$

Table 2. Depth distribution across all stations (Fig. 1) of chlorophyll $a$, bacterial numbers, rate of labelled thymidine (TdR) incorporation, bacterial growth, bactenal population doubling tıme, and bactenal carbon production. Data given are mean \pm standard deviation and range. $N=12$ to 15 for all depths except 500 and $1000 \mathrm{~m}$ where $\mathrm{N}=3 . \mathrm{ND}$ : not determined

\begin{tabular}{|c|c|c|c|c|c|c|c|}
\hline $\begin{array}{l}\text { Depth } \\
(\mathrm{m})\end{array}$ & $\begin{array}{c}\text { Chl a } \\
\left(\mathrm{ng} \mathrm{l}^{-1}\right)\end{array}$ & $\begin{array}{l}\text { Bacteria } \\
\left(\times 10^{8} \mathrm{I}^{-1}\right)\end{array}$ & $\begin{array}{c}\mathrm{TdR} \\
\left(\mathrm{pmol} \mathrm{l}^{-1} \mathrm{~h}^{-1}\right)\end{array}$ & $\begin{array}{c}\text { TdR cell } \\
\left(\times 10^{-21} \mathrm{~mol} \mathrm{cell}^{-1} \mathrm{~h}^{-1}\right)\end{array}$ & $\begin{array}{l}\text { Specific growth } \\
\quad\left(\mathrm{d}^{-1}\right)\end{array}$ & $\begin{array}{l}\text { Doubling time } \\
\text { (d) }\end{array}$ & $\begin{array}{l}\text { Production } \\
\left(\text { ngC l-1 } \mathrm{h}^{-1}\right)\end{array}$ \\
\hline 0 & $\begin{array}{l}64.0 \pm 14.8 \\
45.0-1.02 .5\end{array}$ & $\begin{array}{l}2.81 \pm 0.82 \\
1.50-3.90\end{array}$ & $\begin{array}{l}0.35 \pm 0.33 \\
0.09-1.28\end{array}$ & $\begin{array}{l}1.31 \pm 1.17 \\
0.32-4.27\end{array}$ & $\begin{array}{l}0.022 \pm 0.019 \\
0.005-0.071\end{array}$ & $\begin{array}{c}55.4 \pm 35.8 \\
9.8-129\end{array}$ & $\begin{array}{l}57 \pm 5.3 \\
1.5-20.9\end{array}$ \\
\hline 25 & $\begin{array}{l}71.2 \pm 19.9 \\
53.3-130.0\end{array}$ & $\begin{array}{l}2.65 \pm 0.56 \\
1.70-3.50\end{array}$ & $\begin{array}{l}0.33 \pm 0.20 \\
0.05-0.87\end{array}$ & $\begin{array}{l}1.21 \pm 0.65 \\
0.27-3.01\end{array}$ & $\begin{array}{l}0.020 \pm 0.010 \\
0.005-0.050\end{array}$ & $\begin{array}{l}45.8 \pm 31.8 \\
13.8-152\end{array}$ & $\begin{array}{l}5.1 \pm 3.2 \\
0.9-14.2\end{array}$ \\
\hline 50 & $\begin{array}{r}103.2 \pm 32.2 \\
66.6-163.8\end{array}$ & $\begin{array}{l}2.57 \pm 0.61 \\
1.70-3.50\end{array}$ & $\begin{array}{l}0.32 \pm 0.20 \\
0.01-0.63\end{array}$ & $\begin{array}{l}1.35 \pm 1.12 \\
0.03-3.72\end{array}$ & $\begin{array}{l}0.022 \pm 0.018 \\
0.001-0.062\end{array}$ & $\begin{array}{c}147 \pm 318 \\
11.2-1273\end{array}$ & $\begin{array}{l}5.1 \pm 3.1 \\
0.1-10.3\end{array}$ \\
\hline 75 & $\begin{array}{l}158.8 \pm 22.4 \\
126.5-201.3\end{array}$ & $\begin{array}{l}2.57 \pm 0.73 \\
1.20-3.80\end{array}$ & $\begin{array}{l}0.44 \pm 0.27 \\
0.20-1.17\end{array}$ & $\begin{array}{l}1.93 \pm 1.55 \\
0.58-6.86\end{array}$ & $\begin{array}{l}0.032 \pm 0.025 \\
0.010-0.114\end{array}$ & $\begin{array}{r}30.5 \pm 16.2 \\
6.1-71.6\end{array}$ & $\begin{array}{l}7.2 \pm 4.2 \\
3.3-19.0\end{array}$ \\
\hline 90 & $\begin{array}{l}226.5 \pm 48.0 \\
173.8-355.0\end{array}$ & $\begin{array}{l}2.29 \pm 0.65 \\
1.20-3.30\end{array}$ & $\begin{array}{l}0.19 \pm 0.10 \\
0.06-0.45\end{array}$ & $\begin{array}{l}0.90 \pm 0.53 \\
0.34-2.03\end{array}$ & $\begin{array}{l}0.015 \pm 0.009 \\
0.006-0.034\end{array}$ & $\begin{array}{l}63.7 \pm 34.0 \\
20.6-124\end{array}$ & $\begin{array}{l}3.1 \pm 1.6 \\
1.1-7.3\end{array}$ \\
\hline 100 & $\begin{array}{l}245.9 \pm 66.8 \\
182.5-423.8\end{array}$ & $\begin{array}{l}2.09 \pm 0.46 \\
1.20-2.80\end{array}$ & $\begin{array}{l}0.56 \pm 1.01 \\
0.00-3.91\end{array}$ & $\begin{array}{l}3.62 \pm 8.41 \\
0.00-32.54\end{array}$ & $\begin{array}{l}0.060 \pm 0.134 \\
0.000-0.539\end{array}$ & $\begin{array}{r}36.3 \pm 25.3 \\
0.0-85.6\end{array}$ & $\begin{array}{l}9.1 \pm 1.5 .9 \\
0.0-63.7\end{array}$ \\
\hline 110 & $\begin{array}{l}243.4 \pm 86.1 \\
158.2-430.0\end{array}$ & $\begin{array}{l}1.79 \pm 0.43 \\
1.00-2.50\end{array}$ & $\begin{array}{l}0.26 \pm 0.21 \\
0.06-0.72\end{array}$ & $\begin{array}{l}1.38 \pm 0.96 \\
0.47-3.17\end{array}$ & $\begin{array}{l}0.023 \pm 0.015 \\
0.008-0.053\end{array}$ & $\begin{array}{l}43.8 \pm 22.3 \\
13.2-89.5\end{array}$ & $\begin{array}{l}4.2 \pm 3.3 \\
1.0-11.7\end{array}$ \\
\hline 130 & $\begin{array}{c}145.3 \pm 39.8 \\
62.5-206.2\end{array}$ & $\begin{array}{l}1.53 \pm 0.41 \\
0.70-2.40\end{array}$ & $\begin{array}{l}0.24 \pm 0.16 \\
0.03-0.50\end{array}$ & $\begin{array}{l}1.53 \pm 0.83 \\
0.15-3.33\end{array}$ & $\begin{array}{l}0.025 \pm 0.013 \\
0.003-0.055\end{array}$ & $\begin{array}{l}49.7 \pm 65.9 \\
12.5-279\end{array}$ & $\begin{array}{c}4.0 \pm 2.5 \\
0.44-8.15\end{array}$ \\
\hline 150 & $\begin{array}{l}79.5 \pm 21.8 \\
33.3-106.6\end{array}$ & $\begin{array}{l}1.62 \pm 0.70 \\
1.10-3.50\end{array}$ & $\begin{array}{l}0.11 \pm 0.08 \\
0.01-0.25\end{array}$ & $\begin{array}{l}0.66 \pm 0.39 \\
0.04-1.38\end{array}$ & $\begin{array}{l}0.011 \pm 0.006 \\
0.001-0.023\end{array}$ & $\begin{aligned} 177.6 & \pm 334 \\
30.2 & -1177\end{aligned}$ & $\begin{array}{l}1.8 \pm 1.2 \\
0.1-4.1\end{array}$ \\
\hline 170 & $\begin{array}{r}67.4 \pm 37.8 \\
9.2-141.3\end{array}$ & $\begin{array}{l}1.20 \pm 0.53 \\
0.40-2.40\end{array}$ & $\begin{array}{l}0.21 \pm 0.13 \\
0.01-0.48\end{array}$ & $\begin{array}{l}1.90 \pm 1.24 \\
0.03-4.69\end{array}$ & $\begin{array}{l}0.032 \pm 0.020 \\
0.001-0.078\end{array}$ & $\begin{array}{l}134 \pm 385 \\
8.9-1521\end{array}$ & $\begin{array}{l}3.5 \pm 2.0 \\
0.1-7.9\end{array}$ \\
\hline 200 & $\begin{array}{l}45.2 \pm 38.6 \\
15.8-133.8\end{array}$ & $\begin{array}{l}1.04 \pm 0.29 \\
0.60-1.50\end{array}$ & $\begin{array}{l}0.36 \pm 0.42 \\
0.00-1.07\end{array}$ & $\begin{array}{l}3.26 \pm 3.86 \\
0.00-12.33\end{array}$ & $\begin{array}{l}0.054 \pm 0.062 \\
0.000-0.204\end{array}$ & $\begin{array}{c}45.5 \pm 62.6 \\
0.0-220\end{array}$ & $\begin{array}{l}5.9 \pm 6.5 \\
0.0-17.5\end{array}$ \\
\hline 500 & $\mathrm{ND}$ & $\begin{array}{l}0.93 \pm 0.21 \\
0.70-1.10\end{array}$ & $\begin{array}{l}0.24 \pm 0.29 \\
0.05-0.57\end{array}$ & $\begin{array}{l}3.39 \pm 4.70 \\
0.46-8.81\end{array}$ & $\begin{array}{l}0.056 \pm 0.064 \\
0.008-0.146\end{array}$ & $\begin{array}{r}47.2 \pm 35.2 \\
4.7-91.0\end{array}$ & $\begin{array}{l}3.9 \pm 3.9 \\
0.8-9.3\end{array}$ \\
\hline 1000 & ND & $\begin{array}{l}0.43 \pm 0.15 \\
0.30-0.60\end{array}$ & $\begin{array}{l}0.27 \pm 0.41 \\
0.00-0.74\end{array}$ & $\begin{array}{l}7.43 \pm 10.60 \\
0.00-19.57\end{array}$ & $\begin{array}{l}0.123 \pm 0.143 \\
0.000-0.324\end{array}$ & $\begin{array}{l}5.8 \pm 6.7 \\
0.0-15.2\end{array}$ & $\begin{array}{l}4.4 \pm 5.5 \\
0.0-12.1\end{array}$ \\
\hline
\end{tabular}




\section{Chlorophyll, Bacterial Numbers and Bacterial Production}
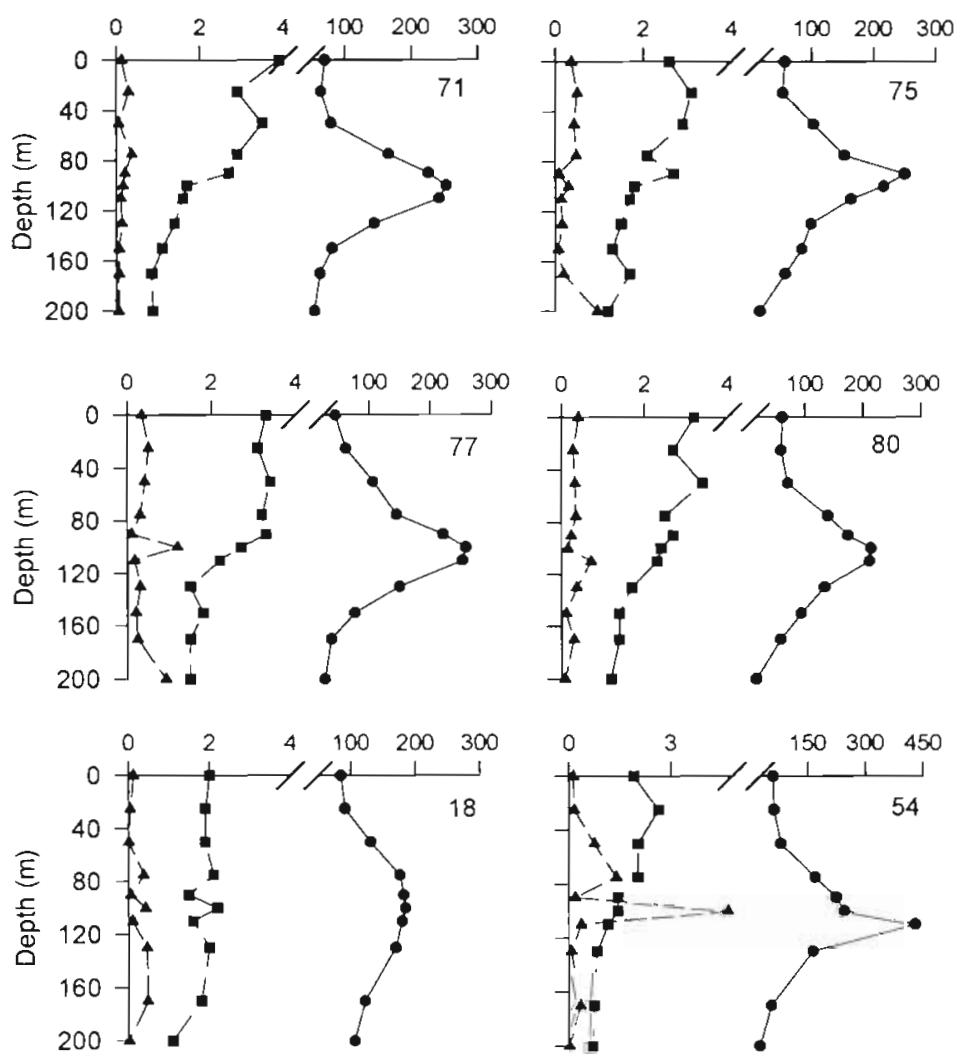

Fig. 2. Representative depth profiles of chlorophyll a concentration (ng $\left.\mathrm{l}^{-1}, \bullet\right)$, bacterial numbers $\left(\times 10^{8}\right.$ cells $\left.\mathrm{l}^{-1}, \mathbf{a}\right)$ and bacterial production ( $p m o l ~ T d R l^{-1} h^{-1}, \mathbf{A}$ ) in the Levantine Basin. Station numbers are given in the upper right corner of each profile; their locations are shown in Fig. 1
Bacterial production ranged from 0 to 3.91 pmol TdR $\mathrm{l}^{-1} \mathrm{~h}^{-1}$ (Table 2). The highest value occurred in the region of the DCM at $\operatorname{Stn} 54$, and while production was also high in the region of the DCM at other stations, this was not generally the situation (Figs. 2, 4B, 5B). Bacterial production along the NW-SE transect tended to decrease with depth (Fig. 5B), which was not commonly the case on the east-west transect (Fig. 5B). Bacterial production was correlated with water temperature $(\mathrm{r}=0.78, \mathrm{p}=0.002)$ at $90 \mathrm{~m}$ and chlorophyll ( $\mathrm{r}=0.60, \mathrm{p}=0.03$ ) at $130 \mathrm{~m}$. It was also inversely correlated with salinity $(r=-0.65$, $\mathrm{p}=0.02)$ at $50 \mathrm{~m}$ and sigma-t $(\mathrm{r}=-0.86, \mathrm{p}=$ 0.0002 ) at $90 \mathrm{~m}$.

Bacterial carbon production ranged from mean values of $1.76 \mathrm{ngC} \mathrm{l}^{-1} \mathrm{~h}^{-1}$ at $150 \mathrm{~m}$ to $9.09 \mathrm{ngC} \mathrm{l}^{-1} \mathrm{~h}^{-1}$ at $100 \mathrm{~m}$ (Table 2). Daily bacterial production for the upper $200 \mathrm{~m}$ of the water column varied from $8.2 \mathrm{mgC} \mathrm{m}^{-2} \mathrm{~d}^{-1}$ at Stn 72 to $43.4 \mathrm{mgC} \mathrm{m}^{-2} \mathrm{~d}^{-1}$ at Stn 79 (Fig. 3).

The specific growth rates for bacteria calculated from the rate of thymidine incorporation varied from undetectable to a maximum value of $0.54 \mathrm{~d}^{-1}$ at $100 \mathrm{~m}$ (Table 2). Mean doubling times ranged from $1.3 \mathrm{~d}$ at $100 \mathrm{~m}$, Stn 54 to $1521 \mathrm{~d}$ at $170 \mathrm{~m}$, Stn 72 . The overall mean for all stations and depths was $70.8 \pm 180.9 \mathrm{~d}(\mathrm{SD})$.
$0.07 \mu \mathrm{m}(\mathrm{SD})$ and a mean volume of $0.049 \pm 0.012$ $\mu^{3}$. We calculated these mean cells had a carbon content of $15.1 \pm 3.7 \mathrm{fgC}$. Rod and comma shaped cells, representing $13 \%$ of the population, had a mean length of $0.93 \pm 0.37 \mu \mathrm{m}$ and a mean width of $0.78 \pm 0.34 \mu \mathrm{m}$ and a mean volume of $0.107 \pm 0.069$ $\mu^{3}$. The mean carbon content of these cells was $24.1 \pm 15.6 \mathrm{fgC}$.

Along the east-west transect bacterial biomass increased from Stn 71, in the east, to Stn 78, in the west, and then decreased (Fig. 3). On the diagonal transect bacterial numbers and biomass were highest in the Ierapetra Eddy (Stns 18 and 12) and in the Mersa Matruh Gyre (Stn 83). Across all stations bacterial biomass $\left(\bar{x}=603 \mathrm{mgC} \mathrm{m}^{-2}\right)$ was on average about $50 \%$ of algal biomass $\left(\bar{x}=1235 \mathrm{mgC} \mathrm{m}^{-2}\right)$ in the upper $200 \mathrm{~m}$. This ratio was generally lower along the diagonal transect with values ranging from 25 to $40 \%(\bar{x}=31 \%)$ whereas along the eastwest transect the range was 52 to $77 \%(\bar{x}=63 \%)$. For all stations, algal and bacterial biomass were weakly inversely correlated $(\mathrm{r}=-0.63, \mathrm{p}=0.01)$.

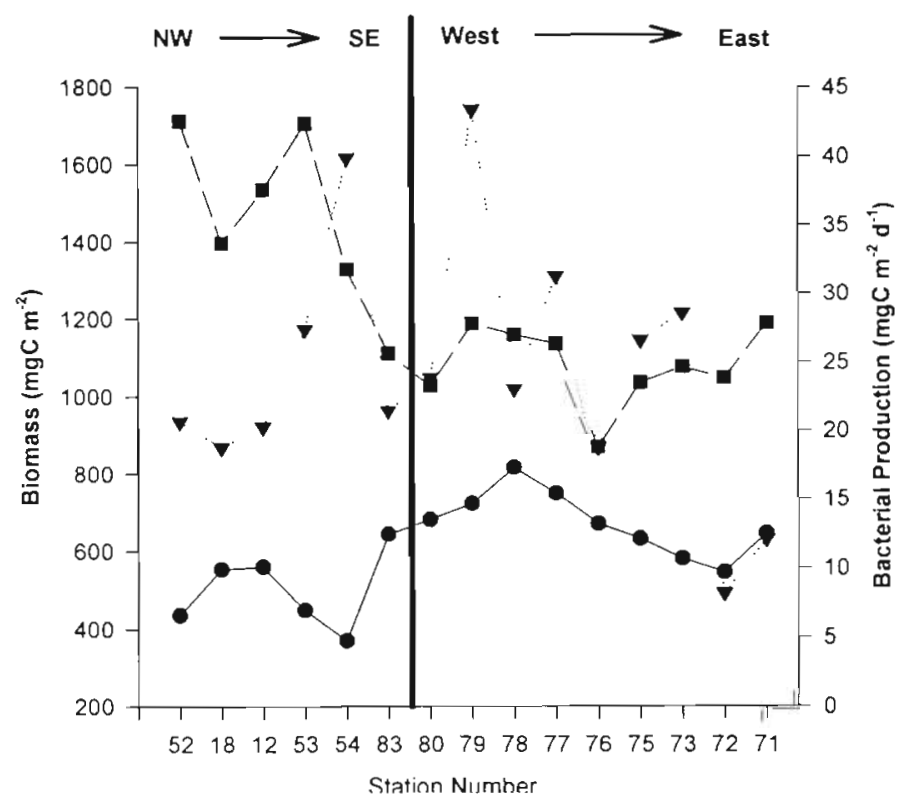

Fig. 3. Integrated (surface to $200 \mathrm{~m}$ ) bacterial (•) and phytoplankton ( $\mathbf{\square}$ biomass and bacterial production (A) along the 2 transects in the Levantine Basin shown in Fig. 1 


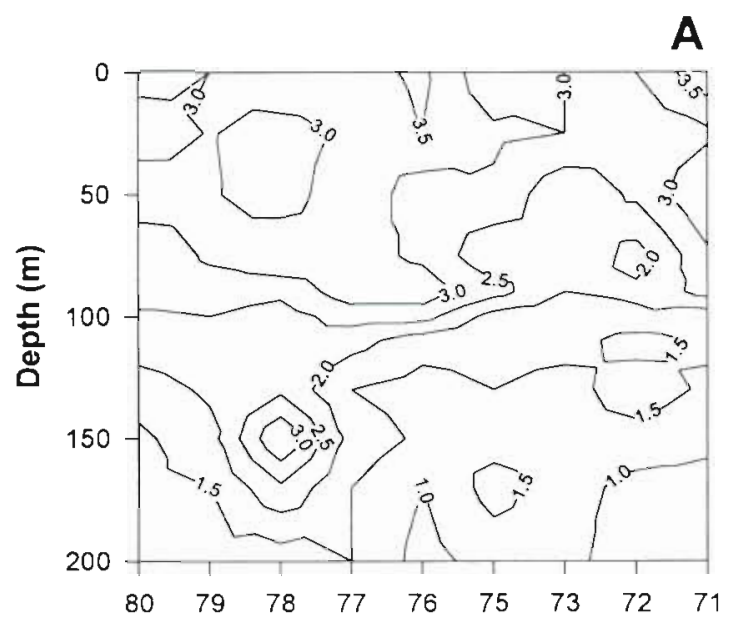

B

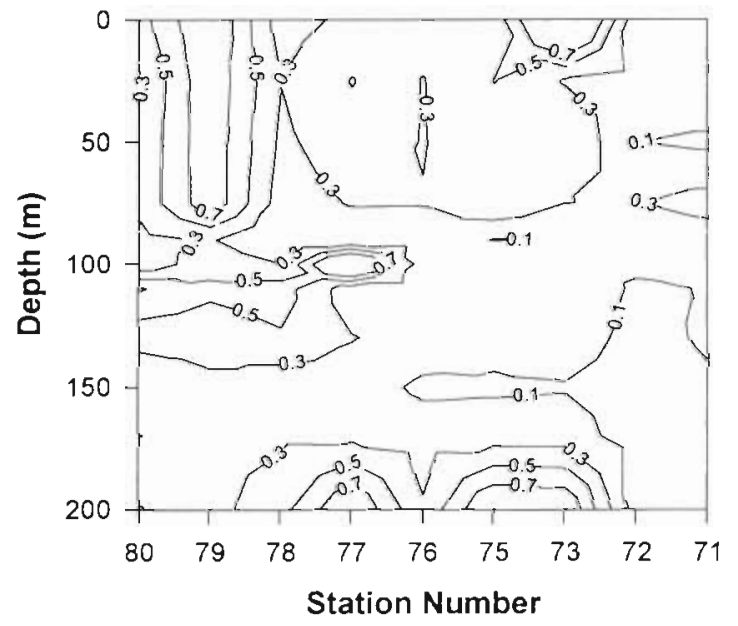

Fig. 4. Spatial distribution of (A) bacterial numbers $\left(\times 10^{8}\right.$ cells $1^{-1}$ ) and (B) bacterial production (pmo] TdR $1^{-1} \mathrm{~h}^{-1}$ ) along the W-E transect in the Levantine Basin shown in Fig. 1

\section{DISCUSSION}

Cho \& Azam (1990) noted that bacterial abundance in the ocean's euphotic zone has a lower threshold of about $3 \times 10^{8}$ cells $1^{-1}$. They concluded that photoautotrophic biomass may decrease well below bacterial biomass with increasingly oligotrophic conditions. Our results from the eastern Mediterranean do not support their conclusions.

In the upper $200 \mathrm{~m}$ of the Levantine Basin the mean chlorophyll concentration was $134 \mathrm{ng} \mathrm{l}^{-1}$ and mean bacterial abundance was $2.03 \pm 0.13 \times 10^{8}(95 \%$ confidence limits, CL) cells $I^{-1}$ (Table 2, Figs. 4A \& 5A). Bird \& Kalff (1984) developed an empirical relationship relating bacterial numbers to chlorophyll concentrations for a wide range of freshwater and marine systems. For the mean chlorophyll concentration from the Levantine Basin this equation accurately predicts a mean bacter-

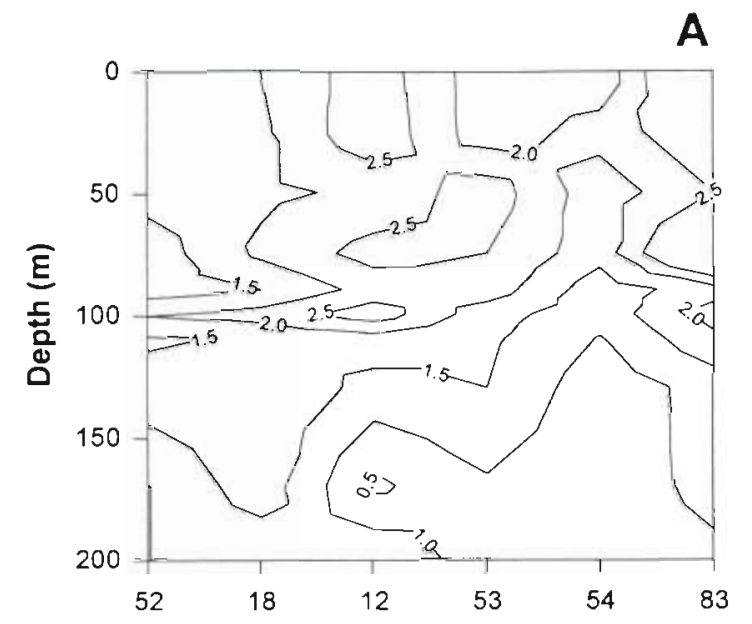

B

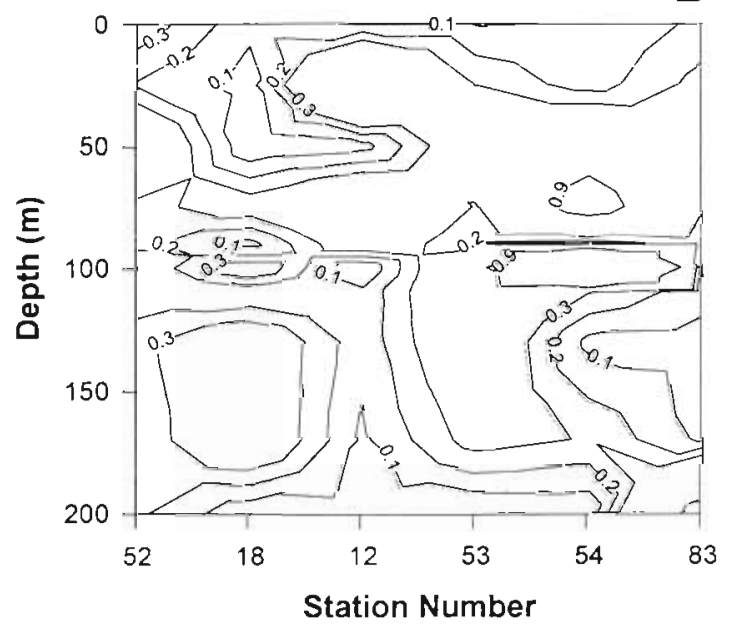

Fig. 5. Spatial distribution of (A) bacterial numbers $\left(\times 10^{8}\right.$ cells $\mathrm{l}^{-1}$ ) and (B) bacterial production (pmol TdR $\mathrm{l}^{-1} \mathrm{~h}^{-1}$ ) along the NW-SE transect in the Levantine Basin shown in Fig. 1

ial number of $1.71 \times 10^{8}$ cells $1^{-1}\left(1.11\right.$ to $2.63 \times 10^{8}$ cells $\mathrm{l}^{-1}, 95 \% \mathrm{CL}$ ). Other equations which have been developed gave less accurate predictions: $3.63 \times 10^{8}$ cells $1^{-1}$, Cole et al.'s (1988) equation for marine and freshwater systems; $11.12 \times 10^{8}$ cells $1^{-1}$, Fuhrman et al.'s (1989)

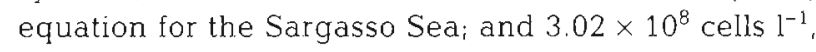
Li et al.'s (1992) equation also for the Sargasso Sea. Bacterial abundance in the Levantine Basin (Figs. 4A \& 5A, Table 2) was similar to that reported by Li et al. (1992) for the Sargasso Sea. At a more southerly station in the Sargasso Sea Fuhrman et al. (1989) found bacterial numbers between 10.9 and $22.3 \times 10^{8}$ cells $\mathrm{l}^{-1}$ in the upper $50 \mathrm{~m}$ of the water column. These cell abundances are significantly higher than those reported by Li et al. and found by us in the Levantine Basin (Figs. 4A \& 5A) although we have previously found up to $6.60 \times$ $10^{8}$ cells $1^{-1}$ in the upper waters of the warm-core Cyprus Eddy (Zohary \& Robarts 1992). 
For the Levantine Basin we calculated that bacterial biomass was 25 to $77 \%(\bar{x}=50 \%)$ of phytoplankton biomass (Fig. 3). In addition to Cho \& Azam (1990) several other studies have been published for oligotrophic marine waters showing that bacterial biomass equals or exceeds phytoplankton biomass (e.g. Hagström et al. 1988, Fuhrman et al. 1989, Li et al. 1992). The outcome of comparing bacterial and phytoplankton biomass depends upon the conversion factors used to calculate the carbon concentration from chlorophyll concentration or cell numbers. Our results differ significantly from these other studies. We calculated phytoplankton biomass using a C:chl of 50 while bacterial biomass was calculated from measured cell volumes and carbon per cell volume based on the data of Simon \& Azam (1989), values which were the same or not unlike that used in the other studies. Suzuki et al. (1993) reported that bacterial cell volumes from Oregon coastal waters estimated using DAPI were only $57 \%( \pm 14 \% \mathrm{SD})$ of volumes measured using Acridine Orange (AO). Our comparison of bacterial cell volumes from the Eastern Mediterranean with other studies of oligotrophic waters, however, remains valid: Hagström et al. and Li et al. stained bacteria using DAPI while Cho \& Azam (1990) used both DAPI and AO. Our data, therefore, support the conclusion by Li et al. (1992) that in oligotrophic oceans bacterial biomass may sometimes dominate phytoplankton biomass, but not always (see also Ducklow \& Carlson 1992). Furthermore, biovolumes of cells stained with DAPI may be closer to the true volume. When Caldwell et al. (1992) compared volumes of cells stained with $\mathrm{AO}$ to those stained with fluorescein using a scanning confocal laser microscope, they found that the volumes of $\mathrm{AO}$ stained cells were $37 \%$ greater than fluoresceinstained cells.

The measurement of bacterial growth and production in natural systems is problematic. Several complex processes affect the accuracy of the estimates obtained and different researchers have used a wide range of conversion factors to derive rates of carbon production and growth (Robarts \& Zohary 1993). The use of such assays, therefore, remains controversial. Of the pulselabelling assays currently being used, thymidine is the substrate which has been most widely employed (Ducklow \& Carlson 1992, Robarts \& Zohary 1993). In addition, when working in very oligotrophic waters such as the eastern Mediterranean, the rates of label incorporation obtained are often at the resolution limits of the method (Figs. 4B \& 5B, Table 2). We have developed a thymidine protocol for use in such waters (Robarts \& Zohary 1993) and while we believe the rates measured in the eastern Mediterranean should be viewed as conservative, we are also confident that they are as accurate as possible given the method and the low biomass. Our variation between replicate live samples was usually $<10 \%$. We are not able to account for the occasional very high rates of TdR incorporation we measured (e.g. Stn 54; Fig. 2) and the rate of 0.74 pmol TdR $\mathrm{l}^{-1} \mathrm{~h}^{-1}$ measured at $1000 \mathrm{~m}$ at Sth 53 seems exceptional (Table 2). The rates of TdR incorporation per cell (Table 2) were within the ranges reported for other freshwater and marine systems (cf. Table 4 in Robarts \& Wicks 1990). We have to assume the measured rates of thymidine incorporation were due to the bacterial community since at the low concentrations of thymidine we used it should not have been available to other microorganisms (Robarts \& Zohary 1993).

The mean rate of $\mathrm{TdR}$ incorporation for all stations and depths in the Levantine Basin was $0.31 \mathrm{pmol}^{-1} \mathrm{~h}^{-1}$ (Figs. 4B \& 5B, Table 2). These rates are at the lower end of values usually reported for open oceans (cf. Ducklow \& Carlson 1992) but are similar to the rates we measured in the Cyprus Eddy. Mean bacterial doubling time in the present study was $70.8 \pm 14.7 \mathrm{~d}$ (SE) (Table 2). These generation times are longer than usually recorded for the open ocean (Fuhrman et al. 1989, Ducklow \& Carlson 1992) but span the range we found associated with the Cyprus Eddy (Zohary \& Robarts 1992) and are similar to the value of $65 \mathrm{~d}$ reported by Cho \& Azam (1988) for the aphotic zone of an oligotrophic north Pacific gyre. For bacterial biomass to dominate phytoplankton biomass, bacterial turnover times must either be substantially longer than that of phytoplankton, or carbon substrates not derived from photosynthesis and grazing on short time scales must be present (Fuhrman et al. 1989, Ducklow \& Carlson 1992). Phytoplankton population turnover rates are considered to be 0.5 to $2 \mathrm{~d}^{-1}$ (Fuhrman et al. 1989, Ducklow \& Carlson 1992). If these rates are applicable to the eastern Mediterranean, it is possible that bacterial biomass could at times exceed phytoplankton biomass in the upper mixed layer.

Few measurements of phytoplankton production exist for the eastern Mediterranean. Berman et al. (1984) estimated daily euphotic zone production to be 40 to $50 \mathrm{mgC} \mathrm{m}^{-2} \mathrm{~d}^{-1}$ or about 10 to $20 \mathrm{gC} \mathrm{m}^{-2} \mathrm{yr}^{-1}$. Other ${ }^{14} \mathrm{C}$-estimates of primary production for the Eastern Mediterranean have ranged between 6 and $20 \mathrm{gC}$ $\mathrm{m}^{-2} \mathrm{yr}^{-1}$ (Dugdale \& Wilkerson 1988) while Dugdale \& Wilkerson have calculated new production from nutrient fluxes to be 5 to $17 \mathrm{gC} \mathrm{m}^{-2} \mathrm{yr}^{-1}$, excluding the Adriatic Sea.

Our bacterial production data are for a single season only and we have not attempted to extrapolate them to an annual value. Berman et al.'s (1984) average daily primary production estimate of $4.5 \mathrm{mgC}^{-2} \mathrm{~d}^{-1}$ extranolates closely $\left(11.3 \mathrm{gC} \mathrm{m}^{-2} \mathrm{yr}^{-1}\right)$ to the average of the available annual rates. Our mean daily bacterial production for the upper $200 \mathrm{~m}$ of the Levantine Basin was 
$24.3 \mathrm{mgC} \mathrm{m}^{-2} \mathrm{~d}^{-1}$ and is about $55 \%$ of daily primary production. The magnitude of the flux of carbon from phytoplankton to bacteria is usually calculated by correcting bacterial production rates for respiration using a growth yield factor Bacterial production estimated from thymidine incorporation is assumed to equal net production in these calculations. Estimates of growth yield diverge widely, ranging from $<0.15$ to 0.9 (Schwaerter et al. 1988). We corrected bacterial production for respiration using a growth yield of 0.35 as recommended by Schwaerter et al. (1988). Bacteria could consume 52 to $276 \%\left(\bar{x}=154 \%\right.$ or $69.3 \mathrm{mgC} \mathrm{m}^{-2}$ $\mathrm{d}^{-1}$ ) of phytoplankton primary production, assuming that all the organic carbon produced by phytoplankton was available to bacteria. Berman et al.'s (1984) phytoplankton production data were for euphotic zones ranging from 100 to $150 \mathrm{~m}$, similar to our values (Table 1), while our bacterial production values were integrated over $200 \mathrm{~m}$. Even if we reduced bacterial production by $50 \%$, bacteria would consume up to $138 \%$ of phytoplankton production. On the other hand, if we had used a conversion factor of $2 \times 10^{18}$ cells produced moi : IdR incorporated into DNA to caìcuiate bacterial growth, the average from a wide range of marine studies (Ducklow \& Carlson 1992), and integrated this data over the euphotic zone only, our original estimate that bacteria could have consumed an average of $154 \%$ of primary production would hold. Hagström et al. (1988) calculated that $60 \%$ of primary production was consumed by bacteria in the oligotrophic, pelagic western Mediterranean.

Our calculations indicate that the bacterial population in the Levantine Basin may be acquiring organic carbon not derived from phytoplankton. Fuhrman et al. (1989) addressed the question of how 2 groups (phytoplankton and bacteria) of similarly sized organisms coexist near steady state when one of them is turning over more rapidly than the other. They considered a number of possibilities including the discrimination against heterotrophs by grazers, photolysis of refractory DOC and supply of labile DOC from rainwater, in addition to the large release of DOC from phytoplankton and release by grazers as proposed by Hagstrom et al. (1988). For the Levantine Basin a first step in accounting for the large imbalance of carbon flux from phytoplankton to heterotrophic bacteria is to obtain good estimates of water column primary production. Townsend et al. (1988) have cautioned that primary production estimates for this region are possibly low because upwelling events may have been missed during routine surveys. If the imbalance remains, other processes and sources such as those considered by Hagstrom et al. (1988) and Fuhrman et al. (1989), as well as the aeolian deposition of Saharan Desert dust and eddies, must be investigated.
Acknowledgements. We thank the captain, A. Ben-Nun, and crew of RV 'Shikmona'. Bacterial counts were done by Vijay Tumber. Bill Li and Michelle Wood provided information on C:chl ratios. Michelle Wood and 2 anonymous referees made valuable suggestions to improve the manuscript. This work was supported by funds provided by the Israeli Ministry of Energy and Infrastructure and the National Hydrology Research Institute, Environment Canada

\section{LITERATURE CITED}

Azam F, Fenchel T, Field JG, Meyer-Reil LA, Thingstad F (1983) The ecological role of water-column microbes in the sea. Mar Ecol Prog Ser 10:257-263

Berman T, Azov Y, Townsend D (1984) Understanding the oligotrophic oceans: can the eastern Mediterranean be a useful model? In: Holm Hansen O, Bolis L, Gillies R (eds) Marine phytoplankton and productivity. Springer Verlag, Berlin, p 101-112

Bird DF, Kalff J (1984) Empirical relationships between bacterial abundance and chlorophyll concentration in fresh and marine waters. Can J Fish Aquat Sci 41:1015-1023

Caldwell DE, Korber DR, Lawrence JR (1992) Imaging of bacterial cells by fluorescence exclusion using scanning confocal laser microscopy. J Microbiol Methods 15:249-261

Cho BC, Azam F (1988) Major role of bacteria in biogeochemical fluxes in the ocean's interior. Nature 332 $441-443$

Cho BC, Azam F (1990) Biogeochemical signifjcance of bacterial biomass in the ocean's euphotic zone. Mar Ecol Prog Ser 63:253-259

Cole JJ, Findlay S, Pace ML (1988) Bacterial production in fresh and salt water ecosystems: a cross-system overview. Mar Ecol Prog Ser 43:1-10

Ducklow HW, Carlson CA (1992) Oceanic bactenal production. Adv Microb Ecol 12:113-181

Dugdale RC, Wilkerson FP (1988) Nutrient sources and primary production in the Eastern Mediterranean. Oceanol Acta 11:179-184

Fuhrman JA, Sleeter TD, Carlson CA, Proctor LM (1989) Dominance of bacterial biomass in the Sargasso Sea and its ecological implications. Mar Ecol Prog Ser 57:207-217

Hagström $\AA$, Azam F, Andersson A, Wikner J, Rassoulzadegan $F(1988)$ Microbial loop in an oligotrophic pelagic marine ecosystern: possible roles of cyanobacteria and nanoflagellates in the organic fluxes. Mar Ecol Prog Ser 49:171-178

Hecht A, Pinardi N, Robinson AR (1.988) Currents, water masses, eddies and jets in the Mediterranean Levantine Basin. J Phys Oceanogr 18:1320-1353

Krom MD, Brenner S, Kress N, Gordon LI (1991) Phosphorus limitation of primary productivity in the Eastern Mediterranean. Limnol Oceanogr 36:424-432

Legendre P, Troussellier M (1988) Aquatic heterotrophic bacteria: modeling in the presence of spatial autocorrelation Limnol Oceanogr 33:1055-1067

Li WKW, Dickie PM. Irwin BD, Wood AM (1992) Biomass of bacteria, cyanobacteria, prochlorophytes and photosynthetic eukaryotes in the Sargasso Sea. Deep Sea Res 39: $501-519$

Megard RO, Berman T (1989) Effects of algae on the Secchi transparency of the southeastern Mediterranean Sea. Limnol Oceanogr 34:1640-1655

Robarts RD, Wicks RJ (1990) Heterotrophic bacterial production and its dependence on autotrophic production in a hypertrophic African reservoir. Can J Fish. Aquat Sci 47 : $1027-1037$ 
Robarts RD, Zohary T (1993) Fact or fiction - bacterial growth rates and production as determined by $\left[{ }^{3} \mathrm{H}\right.$-methyl]thymidine? Adv Microb Ecol 13:371-425

Robinson AR, Golnaraghi M (1993) Circulation and dynamics of the Eastern Mediterranean Sea; quasi-synoptic datadriven simulations. In: Robinson $A R$, Malanotte-Rizzoli $P$ (eds) Physical oceanography of the Eastern Mediterranean Sea. Pergamon Press, Oxford, p 1207-1246

Robinson AR, Golnaraghi M, Leslje WG, Artegiani A, Hecht A, Lazzoni E, Michelato A, Sansone E, Theocharis A, Unluata U (1991) The Eastern Mediterranean general circulation: features, structure and variability. Dyn Atmos Oceans 15:215-240

Salihoglu I, Saydam C. Basturk O, Yilmaz K, Gocmen D. Hatipoglu E, Yllmaz A (1990) Transport and distribution of nutrients and chlorophyll a by mesoscale eddies in the northeastern Mediterranean. Mar Chem 29:375-390

Schwaerter S, Søndergaard M, Riemann B, Jensen LM (1988) Respiration in eutrophic lakes: the contribution of bacterioplankton and bacterial growth yield. J Plankton Res 10 : 515-531

Sherr BF, Sherr EB, Pedrós-Alió C (1989) Simultaneous measurement of bacterioplankton production and protozoan bacterivory in estuarine water Mar Ecol Prog Ser 54: $209-219$

This article was presented by G. Rheinheimer (Senior Editorial Advisor), Kiel, Germany
Simon M Azam F (1989) Protein content and protein synthesis rates of planktonic marine bacteria. Mar Ecol Prog Ser $51: 201-213$

Suzuki MT, Sherr EB, Sherr BF (1993) DAPI direct counting underestimates bacterial abundances and average cell size compared to AO direct counting. Limnol Oceanogr 38: $1566-1570$

Townsend DW, Christensen JP, Berman $T$, Walline $P$, Schneller A, Yentsch CS (1988) Near-bottom chlorophyll maxima in Southeastern Mediterranean shelf waters: upwelling and sediments as possible nutrient sources. Oceanol Acta 11:235-244

Tumber VP, Robarts RD, Arts MT, Evans MS, Caldwell DE (1993) The influence of environmental factors on seasonal changes in bacterial cell volume in two prairie saline lakes. Microb Ecol 26:9-20

Yacobi YZ, Zohary I, Kress N, Hecht A, Robarts RD, Waiser M, Wood AM, Li WKW (1995) Chlorophyll distribution throughout the southeastern Mediterranean in relation to the physical structure of the water mass. J Mar Syst 6: $179-190$

Zohary T, Robarts RD (1992) Bacterial numbers, bacterial production, and heterotrophic nanoplankton abundance in a warm core eddy in the Eastern Mediterranean. Mar Ecol Prog Ser 84:133-137

Manuscript first received: August 16, 1995

Revised version accepted: February 2, 1996 